\title{
Effect of Watery and Alcoholic Medicinal Plants Extractions on In-Vitro Ruminant Digestibility
}

\author{
Shaker A. HASSAN ${ }^{1}$, Jamal A. TAWFFEK ${ }^{1}$, Sajid O. MOHAMMED ${ }^{2}$ \\ ${ }^{1}$ Dept. of Anim. Res., College of Agric., Univ. of Baghdad, Baghdad, Iraq \\ ${ }^{2}$ Dept. of Horticulture, College of Agric., Univ. of Baghdad, Baghdad, Iraq
}

Received (Geliş): 11.06.2014

Accepted (Kabul): 27.10.2014

\begin{abstract}
Two methods of extraction of some medicinal plants, water and alcoholic extractions for Nigella sativa, rosemary, borage, lemon balm and licorice root (Glycyrrhiza glabra) were employed to test their effects on in-vitro rumen digestion trial. Total phenolics contents significantly increased in their water extractions in contrast to their alcoholic extractions. Dry matter digestibility (DMD) significantly increased the water extractions of lemon balm, rosemary and licorice root: $68.47,70.16$ and $73.49 \%$ compared to the control with $76.92 \%$, respectively. Similar trend was observed with organic matter digestibility values (OMD): $69.71,72.93$ and $74.11 \%$ compared to the control with $77.51 \%$, respectively. However, there was an overall significant increase in the studied digestion coefficient values with alcoholic extractions of the same plants. In conclusion, the alcoholic extractions of some medicinal plants can be recommended to be used in ruminant nutrition when these medicinal plant extracts are to be included in their feed for better digestibility values of dry matter and organic matter.
\end{abstract}

Key Words: Medicinal plants, in vitro, digestibility

\section{INTRODUCTION}

Most of medicinal plants have been used as remedies for human diseases because of therapeutic value. In addition some medicinal plants such as Nigella sativa (Black Cumin or Kalonji) oils 36-37\%, crude protein $20-23 \%$ and rosemary were used as additive feed in ruminant animals to improve growth rate and carcass characteristics of Awassi lambs (Hassan and Hassan, 2010; Hassan et al., 2011). Nowadays, medicinal plants extract used as natural preservative in food, cosmetic and pharmaceutical industries. Rababah et al. (2004) work on plant extracts such as green tea and grape seed, the extracts can be used to retard lipid oxidation in a variety of food products. The importance of extracts was to high antioxidants content. Phenolics are the highest contents and most important as antioxidant effect in the medicinal plant extractions, the variety of its concentration due to different factors: Way and time of extraction, harvesting time and the part of plant using for extraction. Phenolics compound reacts as antioxidants because of its ability to be resonancestabilized. There are a lot of phenolics, there effect to the kind of phenolic composition (quality) does not depend on the high content of total phenolics (quantity) in plant or solution (Mhamdi et al., 2010). While ruminant grazing on different kinds of medicinal plants in pasture, phenolics affect negatively on rumen microorganisms activity (Hassan and Tawffek, 2009 and Hassan et al., 2011). So, we select the most common wiled medicinal plants with two extraction methods, watery and alcoholic extraction, to investigate the nutritive value by invitro ruminant digestion coefficient. The medicinal plants were: Nigella sativa, rosemary, borage, lemon balm and licorice root (Glycyrrhiza glabra).

\section{MATERIAL and METHODS}

\section{Preparation and Extraction of Samples}

All medicinal plants used in this research were harvested from the department of medicinal plant in Agriculture College/Baghdad University, sampled and dried at $65^{\circ} \mathrm{C}$ to loss most of the wet then grounded at sieving $1 \mathrm{~mm}$. Two methods of extractions were used at room temperature: watery and ethanol extraction (AlSarraj et al., 1985). In watery method, take $50 \mathrm{gm}$ of samples and put each one in beaker $500 \mathrm{ml}$, fill it with boiled distil water for 30 minutes in stirrer then filtered with cheese cloth extraction, take $50 \mathrm{gm}$ of samples with $250 \mathrm{ml}$ of absolute ethanol for 24 hours, filtered and concentrated to dryness using a rotary evaporator at 50 $-60{ }^{\circ} \mathrm{C}$.

\section{Preparation of Ration}

General ruminants ration for in vitro trial was used as in table 1 and applied at two stages (96h.) of in vitro trial as in Tilley and Terry (1963) as following: Rumen fluid was collected from slaughtered sheep and incubated in water bath at $38^{\circ} \mathrm{C}$. Preparing artificial saliva or buffer solution which consisted of two solutions, first: McDougall's Buffer solution, $49 \mathrm{gm}$ $\mathrm{NaHCO}_{3}+18.6 \mathrm{gm} \mathrm{Na}_{2} \mathrm{HPO}_{4}$ dissolve in $800 \mathrm{ml}$ distilled water. Second: Cloride solution, $28.5 \mathrm{gm} \mathrm{KCl}+23.5 \mathrm{gm}$ $\mathrm{NaCl}+6 \mathrm{gm} \mathrm{MgCl}_{2} .7 \mathrm{H}_{2} \mathrm{O}+2 \mathrm{gm} \mathrm{CaCl}_{2}$ dissolved in $1000 \mathrm{ml}$ distilled water. Add $100 \mathrm{ml}$ from the second solution to the first one $(800 \mathrm{ml})$ and complete the volume up to $1000 \mathrm{ml}$ then incubated in $38^{\circ} \mathrm{c}$ water bath. Preparing in-vitro digestion tubes with $0.5 \mathrm{gm}$ milled rations through a $1 \mathrm{~mm}$ sieve, add $50 \mathrm{ml}$ of solution consisted of $40 \mathrm{ml}$ artificial saliva and $10 \mathrm{ml}$ rumen fluid to each tube then incubated for $48 \mathrm{~h}$ in shaker water bath at $38^{\circ} \mathrm{c}$ with gentle shaking two times a day. After finished $48 \mathrm{~h}$ centrifuged the tubes and re-incubated the

*Corresponding author: Hassan, S.A., shakeratar@yahoo.com 
supernatant $48 \mathrm{~h}$ with $50 \mathrm{ml}$. of $0.2 \%$ pepsin solution (dissolved $0.2 \mathrm{gm}$ pepsin in $100 \mathrm{ml} .0 .1 \mathrm{~N} \mathrm{HCl}$ solution). After finished the second 48h., centrifuged the tubes and dry it $105^{\circ} \mathrm{c}$ overnight. Weight then ash the supernatant at $600^{\circ} \mathrm{c}$ for $5 \mathrm{~h}$. And determine in-vitro dry matter digestibility and organic matter digestibility.
The chemical analysis of grounded ration through a $1 \mathrm{~mm}$ screen was determined according to AOAC (2005) for dry matter (DM), wet, organic matter (OM), crude protein $(\mathrm{CP})$, ether extract $(\mathrm{EE})$, crude fiber $(\mathrm{CF})$, ash and nitrogen free extract (NFE).

Table 1. Formulation \& chemical composition of ingredients and concentrate diet used in the in-vitro trail (\% as dry matter basis)

\begin{tabular}{llllllll}
\hline Chem. Comp. & $\%$ & DM & OM & CP & EE & CF & NFE \\
\hline Ingredients & & & & & & & \\
Barley & 45 & 95.15 & 94.31 & 12.11 & 2.31 & 4.18 & 75.71 \\
Soybean meal & 12 & 96.73 & 93.91 & 46.10 & 2.19 & 3.35 & 42.27 \\
Wheat bran & 40 & 95.33 & 95.88 & 14.89 & 2.52 & 15.89 & 62.58 \\
Bentonite & 1 & ------ & ------ & ------ & ------ & ----- & ----- \\
Min. \& Vit. & 2 & ------ & ----- & ----- & ----- & ---- & ---19 \\
Concentrate & 100 & 95.41 & 94.89 & 16.22 & 2.38 & 10.19 & 66.10 \\
\hline
\end{tabular}

\section{Determination of Total Phenolics}

The amount of total phenolics in extracts was determined with the Folin-Ciocalteu reagent. Tannic acid was used as a standard (figure 1.) and the total phenolics were expressed photometrically as tannic acid equivalents to $100 \mathrm{ml}$ of extract using Lambert-bear law "A $=A_{s} * B * C$ " Where: A(absorption), $A_{s}(0.966)$ from the standard curve, $\mathrm{B}$ (cell diameter $=1$ ) and the $\mathrm{C}$ (total concentration of phenolics) then recalculated as $\%$.

The Folin-Ciocalteu reagent reducing compounds including polyphenols and producing blue color which measured spectrophotometrically at 760nm (Folin, and Denis, 1912).

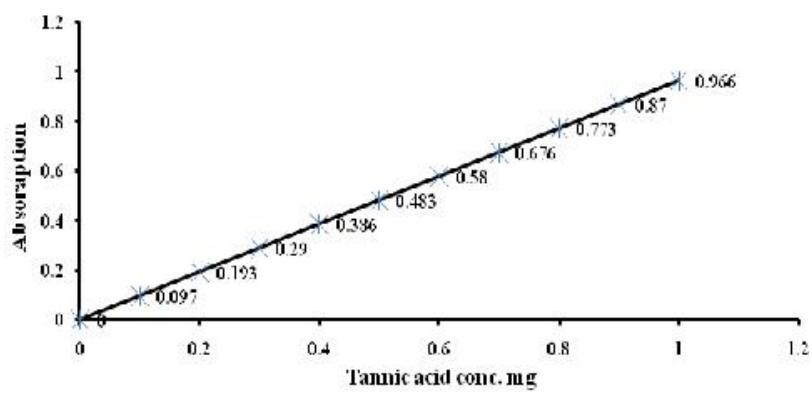

Figure 1. Phenolics standard curve as tonic acid conc.

\section{Statistical Analysis}

For statistical analysis, $2 \times 5$ factorial experiments were used in a completely randomized factorial design (SAS, 2001) and Duncan's multiple ranges tested was used to determine the significant differences between extractions means (Duncan, 1955).

\section{RESULTS and DISCUSSION}

\section{Method of Medicinal Plant Extraction}

In this study, the watery extractions having high significance content of total phenolics in contrasting with alcoholic extractions (Table 2). Phenolics don't soluble in ether or chloroform and other hydrophobic solvents but high soluble in water, alcohol and other hydrophilics (Joslyn, 1950). Water one of the very strong solvents because of its negative and positive charges. So, it can dissolve high amount of phenolics in contrast of alcohol. Sunita and Dhananjay (2010) found the maximum phenolic content in the aqueous extract $(92.4 \pm 0.14 \mathrm{mg} / \mathrm{g})$.

\section{In-vitro dry Matter and Organic Matter Digestibility}

In-vitro ruminants digestion trial was studied with or without addition watery extractions for some medicinal plants: Nigella sativa, rosemary, borage, lemon balm and licorice root in contrast with general ruminants ration as control diet (Table 3 ) then reinvestigated with or without alcoholic extractions for the same medical plants (Table 4). Results indicated that the addition of watery extractions affected negatively $(p<0.01)$ on dry matter digestibility (DMD) with lemon balm, rosemary and licorice root $68.47 \%, 70.16 \%, 73.49 \%$ vas control $(76.92 \%)$ and same effect for organic matter digestibility (OMD) 69.71\%, 72.93\%, 74.11\% in contrast with control $(77.51 \%)$. Negatively increasing the concentration of phenolics affected on rumen microorganisms activity and depress the digestion coefficient in contrast with control. Tanja and Barbara (2009) using rosemary extracts as antimicrobial natural additives to prevent the proliferation of microorganisms or protect food from oxidation by using essential oils or plant extracts as natural additives in foods.

In contrast, the addition of alcoholic extraction (table 4.) increasing digestion coefficient (DMD) from $77.49 \%$ for the control diet up to $80.72 \%, 83.04 \%$, $86.98 \%$ and $88.11 \%$ for rosemary, licorice root, borage and nigella sativa respectively and the same for OMD. This because of two rezones: First, low total phenolics content by alcoholic extraction (Table 2) and second, alcohol can dissolve low chain fatty acids which having great positive effect on increasing ruminant microflora as source of energy (Tawffek and Hassan, 2014) and $60.8 \%$ of oil in Nigella sativa seeds as linoleic acid (essential fatty acids) Nergiz and Otles (1993). No 
differences in digestion coefficient between two methods of extraction, but there are a significance increasing in digestion coefficient with the addition of alcoholic extractions for dry matter content (figure 2.) and for organic matter (Figure 3.). The results agree with Zanouny et al. (2013) to increase digestibility and body weight when Nigella sativa added to the ration of Ossimi male lambs.

Table 2. Total phenolics content in watery and alcoholic extractions for some medicinal plants (mg/ 100ml of extraction) $\pm \mathrm{SD}$

\begin{tabular}{lcc}
\hline \multicolumn{1}{c}{ Treatments } & $\begin{array}{c}\text { Watery extractions } \\
\text { phenolics content }\end{array}$ & $\begin{array}{c}\text { Alcoholic extractions } \\
\text { phenolics content }\end{array}$ \\
\hline Nigella sativa & $0.279^{\mathrm{a}} \pm 0.06$ & $0.155^{\mathrm{b}} \pm 0.07$ \\
Rosemary & $0.408^{\mathrm{a}} \pm 0.04$ & $0.283^{\mathrm{b}} \pm 0.05$ \\
Borage & $0.271^{\mathrm{a}} \pm 0.02$ & $0.107^{\mathrm{b}} \pm 0.04$ \\
Lemon balm & $0.327^{\mathrm{a}} \pm 0.02$ & $0.113^{\mathrm{b}} \pm 0.01$ \\
Licorice root & $0.795^{\mathrm{a}} \pm 0.02$ & $0.355^{\mathrm{b}} \pm 0.01$ \\
\hline
\end{tabular}

Different letters in the same raw indicate differences at 0.01 significance level

Table 3. Effect of watery extractions for some medicinal plants on in-vitro dry and organic matter digestibility (\%) \pm SD

\begin{tabular}{lcc}
\multicolumn{1}{c}{ Treatments } & $\begin{array}{c}\text { In-vitro dry matter } \\
\text { digestion coefficient }\end{array}$ & $\begin{array}{c}\text { In-vitro organic matter } \\
\text { digestion coefficient }\end{array}$ \\
\hline Control & $76.92^{\mathrm{a}} \pm 0.42$ & $77.51^{\mathrm{a}} \pm 0.75$ \\
Nigella sativa & $77.64^{\mathrm{a}} \pm 0.71$ & $78.55^{\mathrm{a}} \pm 0.34$ \\
Rosemary & $70.16^{\mathrm{b}} \pm 0.76$ & $72.93^{\mathrm{b}} \pm 0.78$ \\
Borage & $76.51^{\mathrm{a}} \pm 0.49$ & $77.37^{\mathrm{a}} \pm 0.23$ \\
Lemon balm & $68.47^{\mathrm{b}} \pm 0.61$ & $69.71^{\mathrm{b}} \pm 0.24$ \\
Licorice root & $73.49^{\mathrm{b}} \pm 0.42$ & $74.11^{\mathrm{b}} \pm 0.45$ \\
\hline
\end{tabular}

Different letters in the same column indicate differences at 0.01 significance level

Table 4. Effect of alcoholic extractions for some medicinal plants on in-vitro dry and organic matter digestibility (\%) \pm SD

\begin{tabular}{lcc}
\hline \multicolumn{1}{c}{ Treatments } & $\begin{array}{c}\text { In-vitro } \text { dry matter } \\
\text { digestion coefficient }\end{array}$ & $\begin{array}{c}\text { In-vitro } \text { organic matter } \\
\text { digestion coefficient }\end{array}$ \\
\hline Control & $77.49 \pm 0.34^{\mathrm{c}}$ & $79.08 \pm 0.58^{\mathrm{c}}$ \\
Nigella sativa & $88.11 \pm 0.67^{\mathrm{a}}$ & $90.02 \pm 0.72^{\mathrm{a}}$ \\
Rosemary & $80.72 \pm 0.75^{\mathrm{b}}$ & $82.50 \pm 0.37^{\mathrm{b}}$ \\
Borage & $86.98 \pm 0.56^{\mathrm{a}}$ & $88.84 \pm 0.29^{\mathrm{a}}$ \\
Lemon balm & $78.98 \pm 0.70^{\mathrm{c}}$ & $81.23 \pm 0.34^{\mathrm{c}}$ \\
Licorice root & $83.04 \pm 0.38^{\mathrm{b}}$ & $87.78 \pm 0.35^{\mathrm{a}}$ \\
\hline
\end{tabular}

Different letters in the same column indicate differences at 0.01 significance level

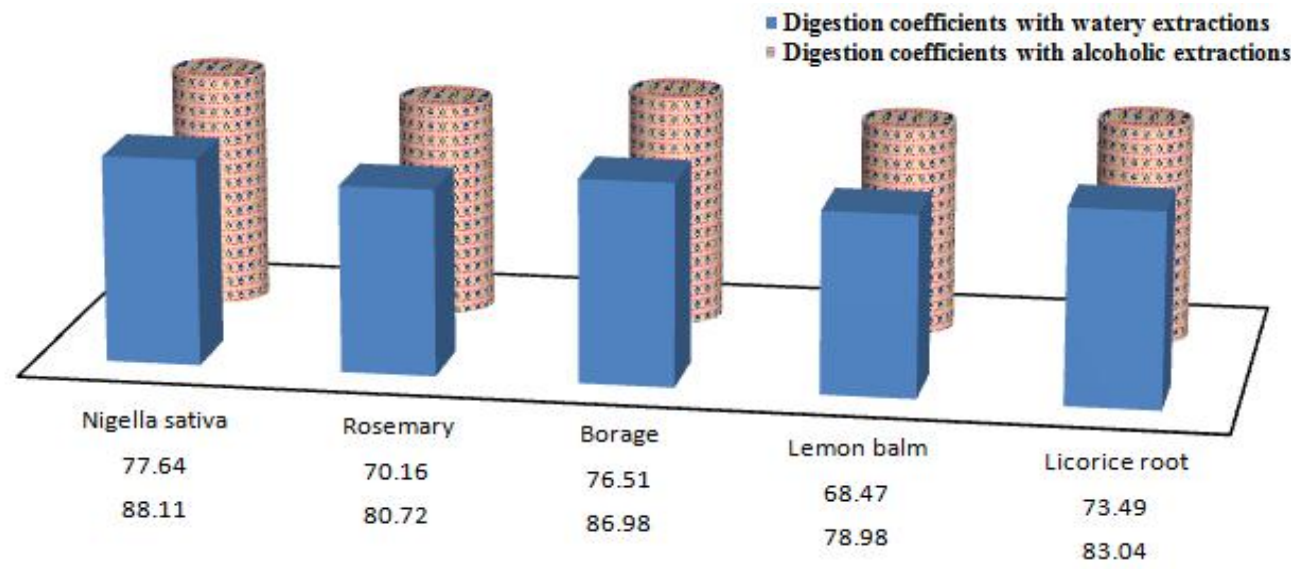

Figure 2. In-vitro dry matter digestion coefficient with watery or alcoholic extractions for some medicinal plants 


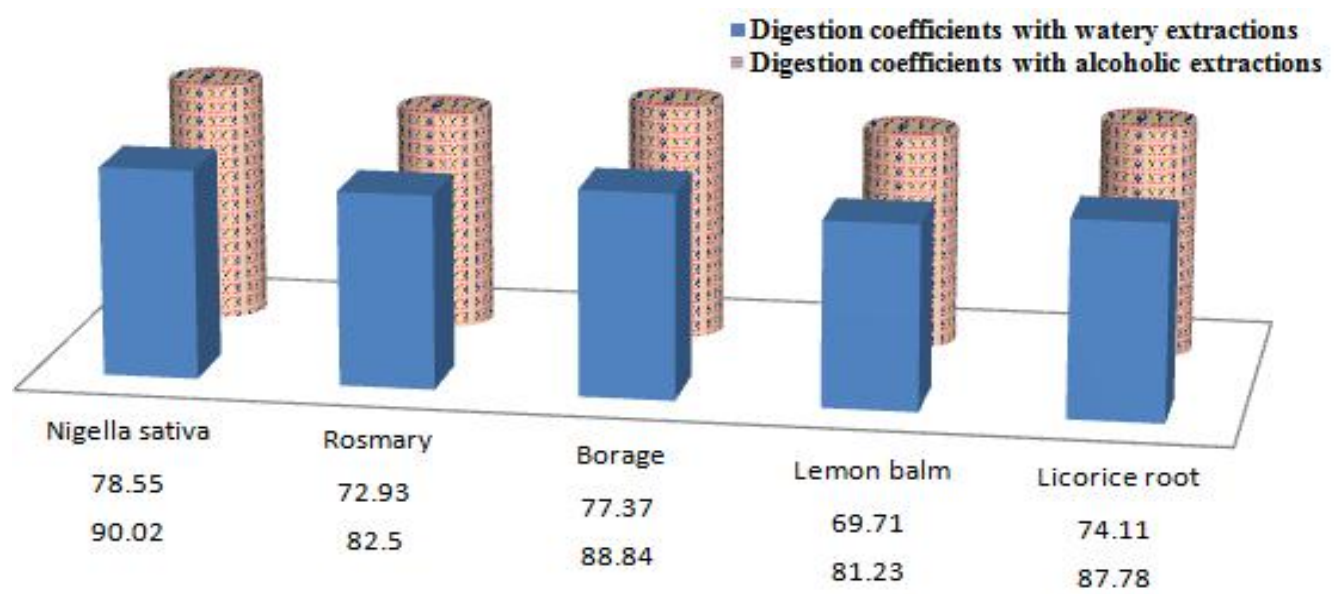

Figure 2. In-vitro organic matter digestion coefficient with watery or alcoholic extractions for some medicinal plants

\section{REFERENCES}

A.O.A.C. 2005. Association of Official Analytical Chemists, Official Methods of Analysis, $19^{\text {th }}$ edn. Washington, DC.

Al-Sarraj, S.M., Redha, F.M.J., Mahmoud, M.J., Hussein,W.A. 1985. Modiced extraction procedure for the active constituents of some Iraqi medicinal plants. Fitoterapia LVI:56-58.

Duncan, D.B. 1955. Multiple ranges and multiple "F" test. Biometrics, 11: 1-12.

Folin, O., Denis, W. 1912. Phosphotungsticphosphomolybdic compound as color reagents. J. Biol. Chem. 12: 239-243.

Hassan, S.A., K.M. Hassan. 2010. The effect of supplementation of medicinal plants and probiotic agent on growth rate and some blood components of karadi lambs. Egyptian J. Applied Sciences, 25(8A):408-419.

Hassan, S.A., Hassan, K.M., Al-Rubeii, A. 2011. Carcass yield and characteristics of Karadi lambs as affected by dietary supplement of rumen under gradable nitrogen fed with Nigella sativa. African J. of Biotechnology, 10(8):1491-1495.

Hassan, S.A., Tawffek, J.A. 2009. Effect of washing and physical form of chemically treated barley straw on nutritive value, phenolic compound and activity of rumen bacteria. 1-Sodium hydroxide treatment. The Iraqi J. of Agricultural Sciences, 40 (1):138-147.

Joslyn, M.A. 1950. Methods in Food Analysis. Applied to plant products. Academic Press Inc. New York.

Mhamdi, B., Aidi Wannes, W., Sriti, J., Jellali, I., Ksouri, R., Marzouk, B. 2010. Effect of harvesting time on phenolic compounds and antiradical scavenging activity of Borago officinalis seed extracts. Industrial Crops and Products, 31(1): 1-4.
Nergiz, C., Otles, S. 1993. Chemical composition of Nigella sativa L. seeds. Food Chem., 38:259.

Rababah, T.M., Hettiarachchy, N,S., Horax, R. 2004. Total phenolics and antioxidant activities of fenugreek, green tea, black tea, grape seed, ginger, rosemary, gotu kola, and ginkgo extracts, vitamin E, and tert-butylhydroquinone. J. Agric. Food Chem., 52 (16):5183-5186.

SAS, 2001. SAS/STAT User's Guide for Personal Computers. Release 6.12. SAS Institute Inc., Cary, NC, USA, p.34-55.

Sunita, M., Dhananjay, S. 2010. Quantitative analysis of total phenolic content in Adhatoda vasica nees extracts. International J. Pharm. Tech. Res., 2(4): 2403-2406.

Tanja, R., Barbara, J. 2009. Antimicrobial activity of rosemary extracts (Rosmarinus officinalis L.) against different species of Listeria. Acta Agricultura Slovenica, 93(1): 51 - 58.

Tawffek, J.A., Hassan, S.A. 2014. Nutrition Science. Al-Dar Aljamaeh Press Inc. Baghdad, Iraq.

Tilley, J.M., Terry, R.A. 1963. A two stage technique for in vitro digestion of forage crops. J. Br. Grassland Sci., 18: 104-111.

Zanouny, A.I., Abd Elmoty, A.K.I., El- Barody, M.A.A., Sallam, M.T., Abd Elhakeam, A.A. 2013. Effect of Nigella sativa seeds supplementation on nutritive values and growth performance of Ossimi sheep. Egyptian J. of Sheep \& Goat Sci., 8 (1):4756. 